\title{
CIÊNCIANATURA
}

\section{Qualitative and quantitative evaluation of urban afforest in the central dis- trict of Salto-SP}

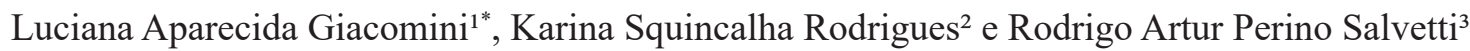

${ }^{1}$ Mestranda em Sustentabilidade na Gestão Ambiental, UFSCAR - Sorocaba, Brasil

${ }^{2}$ Graduada em Ciências Biológicas, CEUNSP - Itu, Brasil

${ }^{3}$ Professor do curso de Ciências Biológicas, CEUNSP - Itu, Brasil

\begin{abstract}
Initially populated by Guayana Indians in the early years of the 17th century, the downtown area of Salto, located in the country of the state of São Paulo, Brazil, has great historical-cultural value and preserves a lush green area. In order to map and assess the afforestation of this area, a census-type survey was carried out from February to September 2017, evaluating all individuals available: trees, shrubs and palm trees planted on sidewalks and flowerbeds. Specimens of all individuals were collected, photographed and georeferenced, and exsicates were assembled to identify the species. The results showed a total of 1,240 individuals belonging to 35 botanical families, being 39,68\% $(n=492)$ native and 60,32\% $(n=748)$ exotic. The problems encountered are related to the lack of planning in the street infrastructure, in which 688 individuals are in cemented areas, 232 individuals damaged the sidewalk, 138 have no room for growth and 229 have the canopy in contact with the wiring. This data demonstrates that the afforestation present in this site requires management and lacks infrastructure.
\end{abstract}

Keywords: Urban arborization; Tree species; Salto

*lucianagiacominni@gmail.com 


\section{Introduction}

Over the last few decades the Brazilian population has become essentially urban. Data from the last demographic census show that the population of inhabitants living in urban areas is $84.4 \%$ (IBGE, 2010). Due to the constant increase in the urbanized areas and its consequent population increase, there is a difficulty of the public administration in the proper planning for the use of the soil, the installation of the urban structures and the afforestation of the urban areas, which results in management problems that directly interfere with the quality of life of man (BIONDI \& LEAL, 2008).

The biggest problems caused by the forestation performed without defined criteria are directly related to the inadequate choice of species interfering with urban equipment, such as wiring, lighting poles, gutters, sidewalks and pipelines (RIBEIRO, 2009). As it points Biondi \& Leal (2008), the urgency to plant a lot of species in a place often causes that there is not enough time to research on each species as unique, which results in the presence of species that can have undesirable characteristics during their growth.

The trees and the green spaces are being increasingly essential and important for a city, because they have ecological and landscape functions (MASCARÓ \& MASCARÓ 2015). A survey of tree species is requested when there is a need to analyze and evaluate species of a region in terms of biodiversity, scientific value (for conservation purposes), and/or its state of preservation. Since there is no such type of study in the region, it was aimed with this work to qualify, quantify and map the road forestation in the central neighborhood of the city of Salto-SP.

The city of Salto is located about $100 \mathrm{~km}$ from the capital of the state of São Paulo and is limited to the north by the city Indaiatuba, to the south and east by the city of Itu and to the west by the city of Elias Fausto. It has an average altitude of 555 meters, with an area corresponding to $133.057 \mathrm{~km}^{2}$ and an estimated population of 115,193 inhabitants (IBGE, 2016). This study was carried out in the Centro district (Figure 1) of Salto, which is composed by 80 blocks and 33 streets, bordering with the districts of Vila Teixeira and Vila Henrique.

\section{Figure 1- Aerial view of Salto-SP, with prominence to the Central District studied}

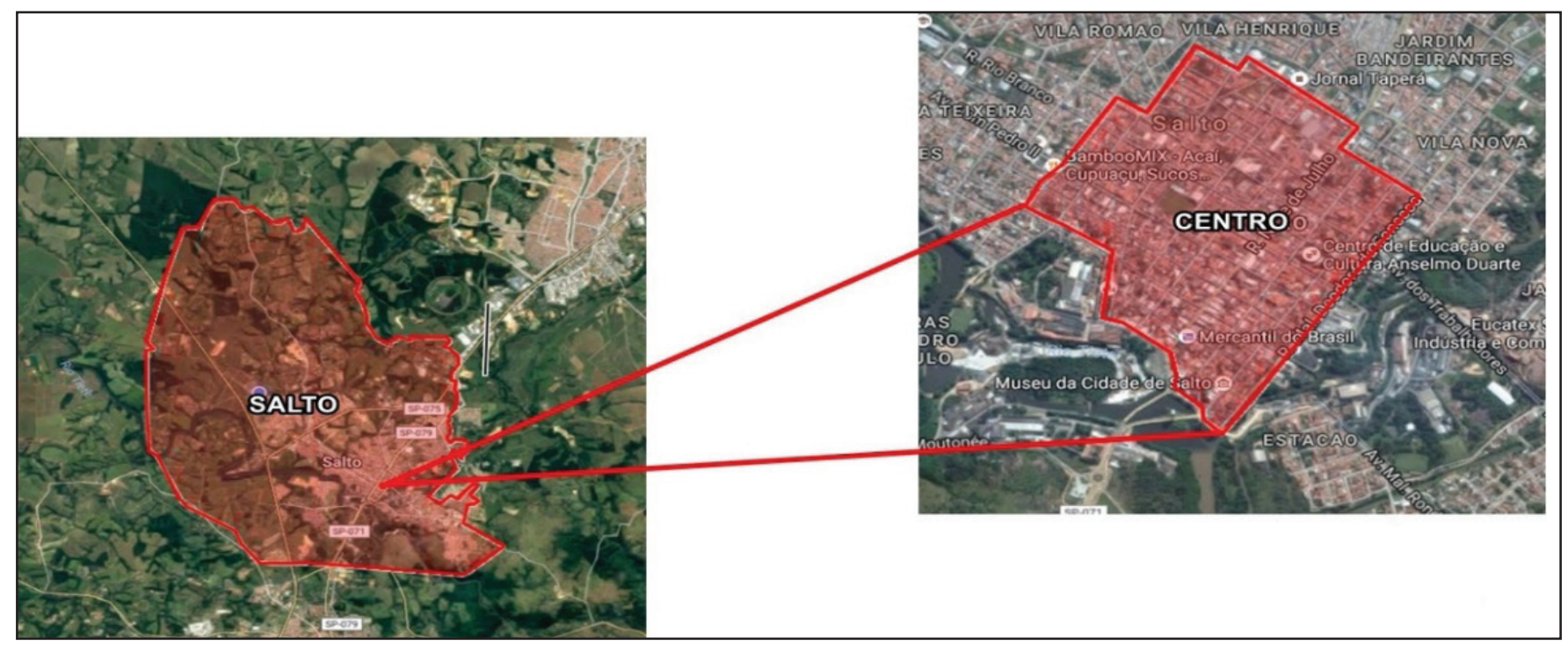

\section{Materials and methods}

The studied area was travelled on weekly visits during the months of February and September/2017, when the data were collected, and the qualitative-quantitative inventory was made, cataloging all the individuals (shrubs and trees) planted on the sidewalks and flowerbeds of the area of interest.

For the lifting of the afforestation was used the method of walking, as described by Filgueiras et al. (1995). This method corresponds to three steps: the first is the recognition of the type of vegetation in the studied area; the second is to draw up the list of species found; and the third is the analysis of the results. For the recognition of the type of vegetation, the neighborhood was walked with the help of aerial photographs and recent maps provided by the municipal government.

An imaginary straight line was drawn along the area in the direction of greater extent, where it ran slowly and noted the names and characteristics of all the species found along the path. In addition to the notes, botanical material was collected from all species evaluated with the aid of a trimmer and a pruning shear for the assembly of exsiccates used for subsequent 
identification of the species. The press assembly followed the order: sheet of cardboard, aluminum foil, sheet of cardboard, newspaper containing the sample to be pressed, sheet of cardboard, aluminum foil and sheet of cardboard (ROTTA, BELTRAMI \& ZONTA, 2008). The pressed exsiccates were taken to the Microbiology Laboratory of the Centro Universitário Nossa Senhora do Patrocínio for drying in electric greenhouse for 48 hours, at $50^{\circ} \mathrm{C}$. After this procedure, the exsiccates were stored in the cabinets of the botanical laboratory of the institution in a provisional nature, to be evaluated as required.

During the survey of the species were also taken the geographical coordinates of every individual, made photographic records and annotated the address (name of street, number and location) of the species in a specific table, as model exposed in Table 1. In this table, general observations were still recorded, such as the identification of the vegetable (scientific and popular name), the physical state of the flowerbed (with or without barrier), the physical state of the sidewalk (broken or not), the spacing of the plant (if it was in contact with the wiring) and even if the plant had enough space for its development.

Table 1 - Form template used in the collection of specimen data by public.

\begin{tabular}{c|c|c}
\hline \multicolumn{3}{|c}{ Address: Rua Floriano Peixoto (calçada direita) } \\
\hline Species number & Species & General observations \\
\hline 1 & Aroeira Salsa (Schinus molle L.) & Canteiro com barreira \\
\hline
\end{tabular}

The georeferenced data was released in Google Earth Pro and separated depending on the attributes described above and organized in the form of a map. The identification of species from the phenological state (presence of flowers and/or fruits) was performed by means of online botanical identification platforms and specific bibliographies.

\section{Results}

In the central district of Salto, 1,240 individuals were found (Figure 2), including trees and shrubs, belonging to 77 different species distributed in 39 botanical families (Table 2).

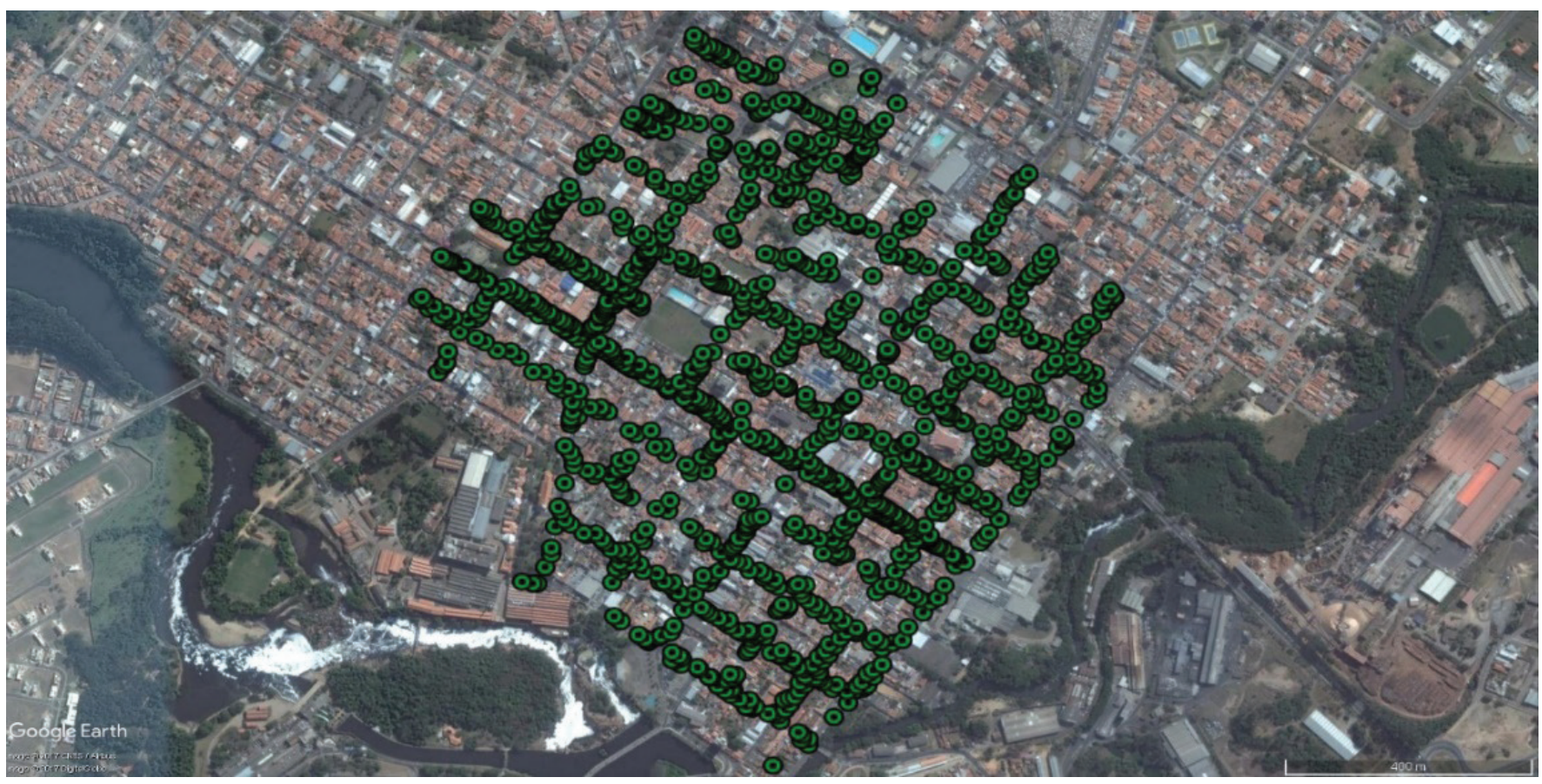

Figure 2 - Individuals found in the center district of Salto/SP. 
Table 2 - Species found in the wooded area of the center district of Salto-SP

\begin{tabular}{|c|c|c|c|c|c|}
\hline Popular name & Scientific Name & Family & $\mathrm{O}^{*}$ & NI* & $\mathrm{F}(\%)^{*}$ \\
\hline Murta de cheiro & Murraya paniculata (L.) & Rutaceae & $\mathrm{E}$ & 226 & $18,23 \%$ \\
\hline Pata de vaca & Bauhinia variegata (L.) & Fabaceae & $\mathrm{E}$ & 147 & $11,85 \%$ \\
\hline Sibipiruna & Caesalpinia pluviosa (DC) & Fabaceae & $\mathrm{N}$ & 88 & $7,10 \%$ \\
\hline Resedá & Lagerstroemia indica (L.) & Lythraceae & $\mathrm{E}$ & 83 & $6,69 \%$ \\
\hline Aroeira Salsa & Schinus molle (L.) & Anacardiaceae & $\mathrm{N}$ & 74 & $5,97 \%$ \\
\hline Ipê de Jardim & Tecoma stans (L.) Jussieu ex Kunth & Bignoniaceae & $\mathrm{E}$ & 65 & $5,24 \%$ \\
\hline Oiti & Licania tomentosa (Benth.) Fritsch. & Chrysobalanaceae & $\mathrm{N}$ & 52 & $4,19 \%$ \\
\hline Escova de Garrafa & Callistemon viminalis (Sol. ex Gaertn.) G. Don & Myrtaceae & $\mathrm{E}$ & 48 & $3,87 \%$ \\
\hline Jerivá & Syagrus romanzoffiana (Cham.) Glassm. & Palmae & $\mathrm{N}$ & 37 & $2,98 \%$ \\
\hline Ipê Roxo & Handroathus impetiginosus (Mart. ex DC.) Mattos & Bignoniaceae & $\mathrm{N}$ & 36 & $2,90 \%$ \\
\hline Ipê Rosa & Handroathus heptaphyllus (Vell.) Mattos & Bignoniaceae & $\mathrm{N}$ & 34 & $2,74 \%$ \\
\hline Pitanga & Eugenia uniflora (L.) & Myrtaceae & $\mathrm{N}$ & 29 & $2,34 \%$ \\
\hline Quaresmeira & Tibouchina granulosa (Cogn.) & Melastomataceae & $\mathrm{N}$ & 25 & $2,02 \%$ \\
\hline Ipê Amarelo & Handroanthus arianeae (A.H. Gentry) S.O. Grose & Bignoniaceae & $\mathrm{N}$ & 24 & $1,94 \%$ \\
\hline Ipê Branco & Tabebuia róseo-alba (Ridl.) Sand & Bignoniaceae & $\mathrm{N}$ & 24 & $1,94 \%$ \\
\hline Alfeneiro & Ligustrum lucidum (W.T.Aiton) & Oleaceae & $\mathrm{E}$ & 21 & $1,69 \%$ \\
\hline Chuva de ouro & Cassia fistula (L.) & Fabaceae & $\mathrm{E}$ & 19 & $1,53 \%$ \\
\hline Hibisco & Hibiscus rosa-sinensis (L.) & Malvaceae & $\mathrm{N}$ & 16 & $1,29 \%$ \\
\hline Espirradeira & Nerium oleander (L.) & Apocynaceae & $\mathrm{E}$ & 14 & $1,13 \%$ \\
\hline Jacarandá & Jacaranda mimosifolia (D. Don) & Bignoniaceae & $\mathrm{E}$ & 12 & $0,97 \%$ \\
\hline Palmeira Imperial & Roystonea oleracea (Jacq.)O.F.Cook & Arecaceae & $\mathrm{E}$ & 9 & $0,73 \%$ \\
\hline Fícus & Ficus benjamina (L.) & Moraceae & $\mathrm{E}$ & 9 & $0,73 \%$ \\
\hline Arvore da china & Koelreuteria bipinnata (Franch.) & Sapindaceae & $\mathrm{E}$ & 9 & $0,73 \%$ \\
\hline Dedaleiro & Lafoensia glyptocarpa (Koehne) & Lythraceae & $\mathrm{N}$ & 7 & $0,56 \%$ \\
\hline Manacá de Jardim & Brunfelsia uniflora (Don.) & Solanaceae & $\mathrm{N}$ & 7 & $0,56 \%$ \\
\hline Acerola & Malpighia glabra (L.) & Malpighiaceae & $\mathrm{E}$ & 6 & $0,48 \%$ \\
\hline Chapéu de napoleão & Thevetia peruviana (Schum.) & Apocynaceae & $\mathrm{N}$ & 6 & $0,48 \%$ \\
\hline Chapéu de sol & Terminalia catappa (L.) & Combretaceae & $\mathrm{E}$ & 6 & $0,48 \%$ \\
\hline Palmeira Areca & Dypsis lutescens (H. Wendl.) & Arecaceae & $\mathrm{E}$ & 6 & $0,48 \%$ \\
\hline Quaresmeira & Tibouchina mutabilis (Cong.) & Melastomataceae & $\mathrm{N}$ & 6 & $0,48 \%$ \\
\hline Canelinha & Nectandra megapotamica (Spreng.) & Lauraceae & $\mathrm{N}$ & 5 & $0,40 \%$ \\
\hline Cróton & Codiaeum variegatum (L.) & Euphorbiaceae & $\mathrm{E}$ & 5 & $0,40 \%$ \\
\hline Goiabeira & Psidium guava $(\mathrm{L})$. & Myrtaceae & $\mathrm{N}$ & 5 & $0,40 \%$ \\
\hline Grevilha & Grevillea banksii (R. Br.) & Proteaceae & $\mathrm{E}$ & 5 & $0,40 \%$ \\
\hline Amora & Morus nigra (L.) & Moraceae & $\mathrm{E}$ & 4 & $0,32 \%$ \\
\hline Camélia & Camelia japônica (L.) & Theaceae & $\mathrm{E}$ & 4 & $0,32 \%$ \\
\hline Cipreste & Cupressus sp (L.) & Cupressaceae & $\mathrm{E}$ & 4 & $0,32 \%$ \\
\hline Pingo de ouro & Duranta repens var. alba. (L.) & Verbenaceae & $\mathrm{E}$ & 4 & $0,32 \%$ \\
\hline Aroeira Vermelha & Schinus lentiscifolius (Marchand) & Anacardiaceae & $\mathrm{N}$ & 3 & $0,24 \%$ \\
\hline Magnólia & Magnolia champaca (L.) Baill. ex Pierre & Magnoliaceae & $\mathrm{E}$ & 3 & $0,24 \%$ \\
\hline Pata de vaca & Bauhinia blakeana (Dunn) & Fabaceae & $\mathrm{E}$ & 3 & $0,24 \%$ \\
\hline Arborícola & Schefflera actinophylla (Endl.) Harms & Araliaceae & $\mathrm{E}$ & 3 & $0,24 \%$ \\
\hline Cereja & Eugenia involucrata (DC.) & Myrtaceae & $\mathrm{N}$ & 3 & $0,24 \%$ \\
\hline Ingá & Inga dulce (Roxb.) Benth. & Fabaceae & $\mathrm{E}$ & 3 & $0,24 \%$ \\
\hline Abricó de macaco & Couroupita guianensis (Aubl.) & Lecythidaceae & $\mathrm{N}$ & 2 & $0,16 \%$ \\
\hline
\end{tabular}


Table 2 - Continuation...

\begin{tabular}{|c|c|c|c|c|c|}
\hline Popular name & Scientific Name & Family & $\mathrm{O}^{*}$ & NI* & $\mathrm{F}(\%)^{*}$ \\
\hline Atemóia & Annona cherimola (Mill) & Annonaceae & $E$ & 2 & $0,16 \%$ \\
\hline Bisnagueira & Spathodea nilotica (Seem.) & Bignoniaceae & $\mathrm{E}$ & 2 & $0,16 \%$ \\
\hline Chuva de ouro & Cassia javanica (L.) & Fabaceae & $\mathrm{E}$ & 2 & $0,16 \%$ \\
\hline Flanboint mirim & Caesalpinia pulcherrima (L.) Sw. & Fabaceae & $\mathrm{E}$ & 2 & $0,16 \%$ \\
\hline Limão & Citrus aurantifolia (Swing.) & Rutaceae & $\mathrm{E}$ & 2 & $0,16 \%$ \\
\hline Mamão & Carica papaya (L.) & Caricaceae & $\mathrm{E}$ & 2 & $0,16 \%$ \\
\hline Palmeira Fenix & Phoenix roebelenii (O’ Brien) & Arecaceae & $\mathrm{E}$ & 2 & $0,16 \%$ \\
\hline Abacate & Persea americana (Mill.) & Lauraceae & $\mathrm{E}$ & 1 & $0,08 \%$ \\
\hline Abiu & Pouteria caimito (Ruiz \& Pav.) Radlk & Sapotaceae & $\mathrm{N}$ & 1 & $0,08 \%$ \\
\hline Acalifa Verde & Acalypha wilkesiana (Müll.Arg.) & Euphorbiaceae & $\mathrm{E}$ & 1 & $0,08 \%$ \\
\hline Albizia & Albizia lebbeck (L.) Benth. & Fabaceae & $\mathrm{E}$ & 1 & $0,08 \%$ \\
\hline Algodão do BrejO & Hibiscus tiliaceus (L.) & Malvaceae & $\mathrm{E}$ & 1 & $0,08 \%$ \\
\hline Araçá & Psidium littorale (L.) & Myrtaceae & $\mathrm{N}$ & 1 & $0,08 \%$ \\
\hline Ateleia & Ateleia guaraya (Herzog) & Fabaceae & $\mathrm{N}$ & 1 & $0,08 \%$ \\
\hline Cajazeira & Spondias mombin (L.) & Anacardiaceae & $\mathrm{N}$ & 1 & $0,08 \%$ \\
\hline Carambola & Averrhoa carambola $(\mathrm{L})$. & Oxalidaceae & $\mathrm{E}$ & 1 & $0,08 \%$ \\
\hline Cássia Siamesa & Senna siamea (Lam.) H.S Irwin \& R.C. Barneby & Fabaceae & $\mathrm{E}$ & 1 & $0,08 \%$ \\
\hline Crista de galo & Celosia cristata (L.) & Amarantaceae & $\mathrm{N}$ & 1 & $0,08 \%$ \\
\hline Embiruçu & Pseudobombax ellipticum (Kunth) Dugand & Bombacaceae & $\mathrm{E}$ & 1 & $0,08 \%$ \\
\hline Figueira Branca & Ficus guaranpitica (Chodat) & Moraceae & $\mathrm{N}$ & 1 & $0,08 \%$ \\
\hline Graviola & Annona muricata (L.) & Annonaceae & $\mathrm{E}$ & 1 & $0,08 \%$ \\
\hline Jabuticaba & Myrciaria cauliflora (DC) O. Berg & Myrtaceae & $\mathrm{N}$ & 1 & $0,08 \%$ \\
\hline Jaca & Arthocarpus heterophyllus (Lam.) & Moraceae & $\mathrm{E}$ & 1 & $0,08 \%$ \\
\hline Janaúba & Euphorbia umbellata (Pax.) Bruyns. & Euphorbiaceae & $\mathrm{E}$ & 1 & $0,08 \%$ \\
\hline Jasmim & Jasminum sp (L.) & Oleaceae & $\mathrm{E}$ & 1 & $0,08 \%$ \\
\hline Romã & Punica granatum (L.) & Lythraceae & $\mathrm{E}$ & 1 & $0,08 \%$ \\
\hline Rosa de Jericó & Hibiscus mutabilis (L.) & Malvaceae & $\mathrm{E}$ & 1 & $0,08 \%$ \\
\hline Pau-Brasil & Paubrasilia echinata (Lam.) & Fabaceae & $\mathrm{N}$ & 1 & $0,08 \%$ \\
\hline Pau-Ferro & Caesalpinia leiostachya (Benth.) Ducke & Fabaceae & $\mathrm{N}$ & 1 & $0,08 \%$ \\
\hline Pokam & Citrus sp (L.) & Rutaceae & $\mathrm{E}$ & 1 & $0,08 \%$ \\
\hline Mussaenda & Mussaenda erythrophylla (Schumach \& Thonn.) & Rubiaceae & $\mathrm{E}$ & 1 & $0,08 \%$ \\
\hline Singônio & Syngonium podophyllum (Schott) & Araceae & $\mathrm{E}$ & 1 & $0,08 \%$ \\
\hline Total & & & & 1240 & $100,00 \%$ \\
\hline
\end{tabular}

${ }^{*} \mathrm{O}=$ origin, being $(\mathrm{N})$ native or (and) exotic; $\mathrm{NI}=$ number of individuals; $\mathrm{F}=$ frequency $(\%)$.

\section{Discussion}

Of the 1,240 individuals found, 492 (39.68\%) are native species and $748(60.32 \%)$ belong to exotic species. Although the planting of native species is recommended, the exotic species should not be excluded from a forestry project, as they play an important landscape role. However, since afforestation has important functional role and environmental services and interactions with the native fauna, the use of exotic species puts at risk the project (PAIVA, 2009).

The species murta de cheiro (Murraya paniculata) was the most abundant in the studied district $(\mathrm{n}=226,18.23 \%$ of the total of individuals found), followed for pata de vaca (Bauhinia forficata) ( $\mathrm{n}=147,11,85 \%$ ) and sibipiruna (Caesalpinia pluviosa) $(\mathrm{n}=88,7,10 \%)$.

It is recommended to use species with ports compatible with the space that will be used for your deployment. The recommended species for the sidewalks are in the small and medium sized group, as they do not interfere with the electrical wiring. The large size species are most recommended to be planted in open spaces such as parks and forests (CPFL, 2008). It was 
observed that the most abundant species, Murraya paniculate, is part of the recommended group for this type of afforestation.

In this survey, 688 of the individuals have the surroundings cemented, which is what causes more breaks and cracks in the sidewalk by the lack of free area for the growth of the plant (SILVA, PAIVA \& GONÇALVES, 2007). It was observed that 232 of the individuals found caused damage to the sidewalks. RABER \& REBELLETO (2010) claim that the use of species with little deep root system in a small area may end up compromising the sidewalk, because the lack of free area does not allow the infiltration of rainwater and nutrients to the plant, causing your bad development.

The species of sibipiruna (Caesalpinia pluviosa) and of chapéu de sol (Terminalia catappa) identified are not suitable for planting on sidewalks, because they contain many aggressive roots that can damage the pavement (Figure 3 A-B). From the moment there is not enough space for the roots to settle, the species expands its roots strongly causing cracks, situation observed in 138 individuals.

Figure 3 - (a) Sibipiruna (Caesalpinia pluviosa DC.) cracking the sidewalk of Rodrigues Alves Street. (b) Chapéu de sol (Terminalia catappa L.) cracking the sidewalk at Presidente Bernardes street.

(a)

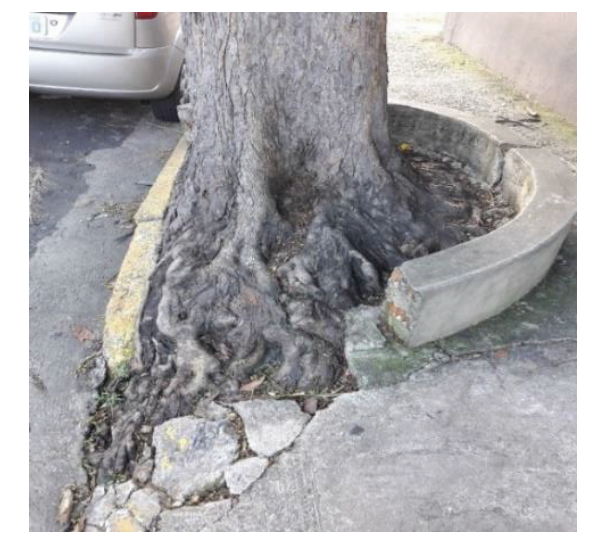

(b)

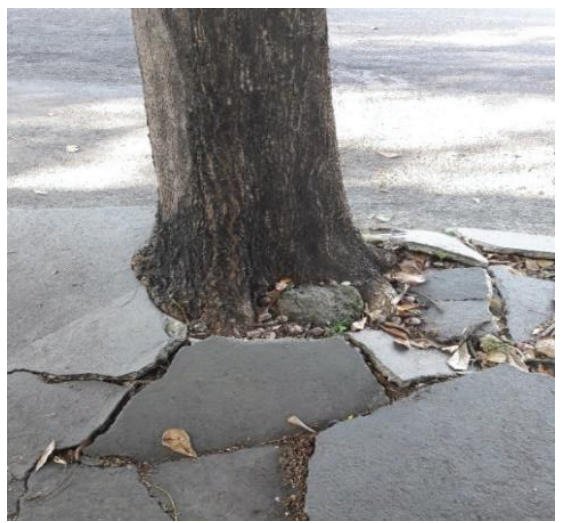

However, even species that are not indicated for the footwear can be managed in such a way as not to cause this kind of damage, for example, with the increase of the area of the site where it is planted. Additionally, it was observed that the damage caused on the sidewalks increases with the growth of the tree, since small species rarely cause problems on the sidewalk.

It was also found that 229 individuals considered to be of large size caused interference in the telephone and electrical wiring. According to MARQUES (2005), it is almost impossible to replace all the trees that interfere in some way with the aerial wiring, even more in the case of urban trees protected individually by Law n ${ }^{\circ}$ 4.771/1965 (Brazilian Forest Code), which in its article $7^{\circ}$ stipulates that "Any tree may be declared immune from cutting, through an act of public power, by reason of its location, rarity, beauty or conditions of seed-bearing". Furthermore, in places where there is such a problem, the costs and benefits involved in pruning, renovation of the lighting network or the replacement of the forestry should be pointed out to choose the best option to be taken.

\section{Final considerations}

According to the results obtained in this work, it was noticed that there is a lack of planning of the afforestation in the city of Salto-SP, both in the choice of tree species to be planted, as in the maintenance and management of the species.

It is necessary the development of a project, jointly with the city hall, and mainly for new districts and parks, in order not to make the same misconceptions identified in the central area of the city. This type of project can be carried out with the participation of schools and the population itself, with the educational purpose of showing how important urban afforestation is.

Since this work is unique in the municipality, it is recommended to carry out other surveys in other districts of the city, with the intention of recognizing the state in which the forestation is, so that the care and practices of management are taken.

\section{References}

BIONDI, D.; LEAL, L. Caracterização das plantas produzidas no horto municipal da barreirinha - Curitiba / PR. Revista Sociedade Brasileira de Arborização Urbana. 2008, v.2, p. 20-36. 
COMPANHIA PAULISTA DE FORÇA E LUZ. Arborização Urbana Viária: aspectos de planejamento, implantação e manejo. Rev. Eletr. Campinas [Internet]. 2008:1-60. Available from: https://www.cpfl.com.br/energias-sustentaveis/ meio-ambiente/Documents/Guia_Arboriza\%C3\%A7\%C3\%A3o_Meio_Ambiente.pdf.

FILGUEIRAS, T. S. et al. 1994. Caminhamento - um método expedito para levantamentos florísticos qualitativos. Cadernos de Geociências. 1995, v. 12, n.1, p. 39-43.

INSTITUTO BRASILEIRO DE GEOGRAFIA E ESTATÍSTICA - IBGE [Internet]. Censo Demográfico 2010: características da população e dos domicílios. 2010. Available from: http://biblioteca.ibge.gov.br/visualizacao/periodicos/93/ cd_2010_caracteristicas_populacao_domicilios.pdf.

INSTITUTO BRASILEIRO DE GEOGRAFIA E ESTATÍSTICA - IBGE [Internet]. Cidades. 2016. Available from: https://cidades.ibge.gov.br/brasil/sp/salto/panorama.

LEI N. 4.771 DE 15 DE SETEMBRO DE 1962. Institui o Novo Código Florestal. Diário Oficial da União (Brasília). 1962 Set 62.

MARQUES, J. R. Meio ambiente urbano. Rio de Janeiro: Forense Universitária, 2005.

MASCARÓ, L.; MASCARÓ, J. L. Vegetação urbana. 4. ed. Porto Alegre: Editora Masquatro, 2015.

PAIVA, A. V. Aspectos da arborização urbana do centro de Cosmópolis - SP. Revista Sociedade Brasileira de Arborização Urbana. 2004, v. 4, n. 4, p. 17-31.

RABER, A. P.; REBELATO, S. R. Arborização viária do município de Colorado, RS - Brasil: análise quali-quantitativa. Revista Sociedade Brasileira de Arborização Urbana. 2012, v. 5, n. 1, p. 183-199.

RIBEIRO, F. A. B. S. Arborização urbana em Uberlândia: percepção da população. Revista da Católica. 2009, v. 1, n. 1, p. 224-237.

ROTTA, E.; BELTRANI, L. C. C.; ZONTA, M. Manual de Prática de Coleta e Herborização de Material Botânico. Embrapa Florestas, 2008: 1-31.

SILVA, A. G. da; PAIVA, H. N. de; GONÇALVES, W. Avaliando a arborização urbana. Viçosa: Aprenda Fácil, 2007. 